I heard the sharp "peek" call characteristic of both grosbeak species. The bird was calling from a small copse of trees 25-30 feet in height, which we both entered in order to find and identify the caller. I saw the bird perched at the top of one of the trees, and identified it as a male Black-headed Grosbeak. The head was black, with a yellowish-brown eyeline reaching to slightly above the eye. The chest, belly, and nape were the same orange-brown colour as the eyeline. The wings and tail were black, with conspicuous white markings. I called to Mr. Holtz, so that he could see the bird also, but as I did, the bird took alarm and flew off. We saw no other grosbeaks of either species that day.

The Black-headed Grosbeak breeds mainly in southern British Columbia, and occasionally in the Cypress Hills area of Saskatchewan and Alberta. According to Godfrey (The birds of Canada, Natl. Mus. Can. Bull. 203, $1966)$, it often ranges far to the east of its breeding range in fall, and has occurred in Saskatchewan at Regina, Estevan, Lake Johnston, and near Armley. In Manitoba, it has strayed to Treesbank and Delta.

Only a few hundred yards and 10 minutes later, we came upon a Townsend's Sclitaire perched in a small bare tree about five feet from the ground. This bird was exceedingly tame, and allowed us to examine it at close range from several angles. It matched the illustration on page 231 of Birds of North America (Robbins, et al, 1966) perfectly, its prominent white eye ring, greyish-brown underparts, and slightly notched tail separating it from the Mockingbird. We observed the Solitaire for about five minutes, at the end of which time it flew to the top of a taller tree about 20 yards away. When we left, it was still perched in this tree.

The occurrence of Townsend's Solitaire in Saskatchewan has been summarized by Sealy (Blue Jay, 29:184196, 1971).

\title{
TOWNSEND'S SOLITAIRE NESTING IN CYPRESS HILLS, ALBERTA
}

\author{
by Edgar T. Jones, 6115-141st St., Edmonton
}

EDITOR'S NOTE: According to Salt and Wilk (The birds of Alberta, Second Ed., 1966) Townsend's Solitaire has not been recorded nesting outside of the mountains and foothills of southwestern Alberta. Thus, the present observation is a first record for Cypress Hills as well as for the region outside of the foothills. Sealy recently reviewed all records of this species in Saskatchewan (Blue Jay, 29 :188190), December 1971).

During August 1971, Rod Burns, my son Gary and I spent several days in the Cypress Hills Provincial Park, near Elkwater, Alberta. On August 2nd we discovered what appears to be the first nest of this species for the region. The nest, which was a bulky affair of dried weeds and grasses, contained four young approximately twothirds grown. Both adults were in attendance and both were filmed at and near the nest. The nest was about eight feet above the hottom of a 50 foot conglomerate cliff, the base of which had slid away in past years The nest was in a small, natural hollow about 10 inches in depth on the face of the cliff. A second nest found within 50 feet of the first seemed to have been built the same year. It was in an excellent state of repair and although empty there was no visible sign of predation.

We were impressed with the wide variety of birds and flowers in the vicinity, many of which one normally associates with the mountain regions. Red Crossbills were common, and Pine Siskins, Myrtle Warblers, Red-breasted Nuthatches, Goshawks, and Swainson's Hawks were also observed. On previous visits to the area, Audubon's Warbler, MacGillivray's Warbler and Yellowthroats were observed. 